\title{
Cloning and Expression Analysis of Phytoplasma Protein Translocation Genes
}

\author{
Shigeyuki Kakizawa, ${ }^{1}$ Kenro Oshima, ${ }^{1}$ Tsutomu Kuboyama, ${ }^{1}$ Hisashi Nishigawa, ${ }^{2}$ Hee-young Jung, ${ }^{2}$ \\ Toshimi Sawayanagi, ${ }^{2}$ Tsuneo Tsuchizaki, ${ }^{3}$ Shin-ichi Miyata, ${ }^{1}$ Masashi Ugaki, ${ }^{1,2}$ and \\ Shigetou Namba ${ }^{1,2}$ \\ ${ }^{1}$ Graduate School of Frontier Sciences, University of Tokyo, Bunkyo-ku, Tokyo 113-8657, Japan.; ${ }^{2}$ Graduate \\ School of Agricultural and Life Sciences, University of Tokyo, Bunkyo-ku, Tokyo 113-8657, Japan; \\ ${ }^{3}$ Koibuchi College of Agriculture, Uchihara-machi, Ibaraki 319-0323, Japan \\ Submitted 16 March 2001; Accepted 28 May 2001.
}

Genes encoding SecA and SecY proteins, essential components of the Sec protein translocation system, were cloned from onion yellows phytoplasma, an unculturable plant pathogenic bacterium. The $\sec A$ gene consists of 2,505 nucleotides encoding an 835 amino acid protein $(95.7 \mathrm{kDa})$ and shows the highest similarity with $\operatorname{Sec} A$ of Bacillus subtilis. Anti-SecA rabbit antibody was prepared from a purified partial SecA protein, with a histidine tag expressed in Escherichia coli. Western blot analysis confirmed that SecA protein (approximately $96 \mathrm{kDa}$ ) is produced in phytoplasma-infected plants. Immunohistochemical thin sections observed by optical microscopy showed that SecA is characteristically present in plant phloem tissues infected with phytoplasma. The secY gene consists of 1,239 nucleotides encoding a 413 amino acid protein $(45.9 \mathrm{kDa})$ and shows the highest similarity with SecY of $B$. subtilis. These results suggest the presence of a functional Sec system in phytoplasmas. Because phytoplasmas are endocellular bacteria lacking cell walls, this system might secrete bacterial proteins directly into the host cytoplasm. This study is what we believe to be the first report of the sequence and expression analysis of phytoplasma genes encoding membrane proteins with a predicted function.

Phytoplasmas, formerly called mycoplasma-like organisms (MLOs), are endocellular bacteria lacking cell walls that are classified into the class Mollicutes. Phytoplasmas cause numerous plant diseases by inhabiting phloem sieve elements and are transmitted between plants by phloem-feeding insects (Kirkpatrick 1992; Lee and Davis 1992; McCoy et al. 1989). Phytoplasmas are small enough to pass through bacteriological filters and, like mycoplasmas, are resistant to antibiotics, interfering with cell wall formation. Although they constitute a large group of phytopathogenic microorganisms (Namba et al. 1993), the inability of in vitro culture has hindered analysis of their genetic components at the molecular level, except for phylogenetic analysis with rDNA sequences.

Corresponding author: S. Namba; Telephone: +81 424693125 ; Fax: +81 42469 8786; E-mail: snamba@ims.u-tokyo.ac.jp

Sequence data deposited in GenBank, accession no. AB056578.
The membrane proteins of phytoplasmas are thought to interfere directly with the cytoplasm of the host plant and insect cells. Until now, five immunodominant membrane protein genes have been cloned from aster yellows (Barbara et al. 1998), sweet potato witches' broom (Yu et al. 1998), apple proliferation (Berg et al. 1999), clover phyllody (Davies et al. 1999), and Western X disease phytoplasmas (Blomquist et al. 2001). The function of these phytoplasmic proteins, however, is uncertain, and no genes encoding membrane proteins with this known function have been cloned.

Many bacteria that are pathogenic in animals secrete toxic proteins such as Corynebacterium diphtheriae (diphtheria toxin) (Murphy et al. 1974; Pappenheimer 1977) and Vibrio cholerae (RTX toxin) (Spangler 1992). Plant-pathogenic bacteria such as Pseudomonas syringae also are known to secrete toxic proteins (Wei et al. 2000). Recently, a plant-pathogenic bacterium, Xylella fastidiosa, which inhabits plant xylem tissues, was reported to encode a putative toxic protein in its genome, similar to the RTX toxin (Simpson et al. 2000). These pathogenic bacteria are known to secrete toxic proteins during infection, thus the protein secretion pathway of these bacteria is important in understanding their pathogenicity.

In bacteria, there are at least five independent protein export systems (Economou 1999). In Escherichia coli, these systems not only constitute membranes and cell envelope export systems, but also secrete various proteins such as toxins, adhesins, and hydrolytic enzymes. Of these systems, only the Sec system is essential for cell viability. In Bacillus subtilis, the Sec pathway is thought to be the most important of four distinct transport pathways (Tjalsma et al. 2000). This study reports on the cloning and sequencing of the putative $\sec A$ and $\sec Y$ genes of the Sec system from onion yellows phytoplasma (OY). Immunohistochemical analysis showed that the $\sec A$ gene is expressed only in phloem tissues of infected plants that phytoplasmas are known to inhabit.

\section{RESULTS}

Cloning and sequence analysis of the $\sec A$ gene.

Total DNA was extracted from the OY-enriched fraction of infected garland chrysanthemum plants, according to the procedures of Kuboyama et al. (1998). The DNA was digested with $\mathrm{XbaI}$ or HindIII and cloned into pUC18 to construct a genomic plasmid library. Two clones containing 2.2- and 0.5- 
$\mathrm{kb}$ inserts were identified from the genomic DNA library of OY by dot blot hybridization with DNA extracted from the OY-enriched fraction (Kuboyama et al. 1998). Insert DNA from these clones was sequenced completely on both strands.

The $0.5-\mathrm{kb}$ insert contained an incomplete open reading frame (ORF) of 154 amino acids. BLAST search analysis demonstrated a strong amino acid sequence similarity to the SecA proteins of B. subtilis, mycoplasmas, and several other prokaryotes. The $0.5-\mathrm{kb}$ insert was used as a probe to screen the genomic plasmid library by colony hybridization. A genomic clone was subsequently identified containing a 5,506bp HincII fragment.

The clone contained three complete ORFs (Fig. 1A). The first ORF (ORF-A1; 2,505 bp) consists of 835 amino acids (approximately $95.7 \mathrm{kDa}$ ) and encodes a protein that is homologous with SecA of several bacteria. ORF-A1 showed stronger similarities to SecA proteins of gram-positive bacteria, B. subtilis (44.5\% identity), and Staphylococcus aureus (43.8\% identity) than it did to mollicute mycoplasma ( $M y$ coplasma genitalium, $39.1 \%$ identity) and gram-negative bacteria (E. coli, $36.7 \%$ identity). The amino acid sequence alignment of OY SecA and SecA proteins from several other prokaryotes is shown in Figure 2. A consensus amino acid pattern of SecA registered at PROSITE was conserved in OY SecA (Fig. 2). The second and third ORFs (ORF-A2 and ORF-A3) encoded 330 and 242 amino acids, respectively. These putative coding regions were similar in amino acid sequence to chain release factor B (RF-2) and tRNA-(guanine$\mathrm{N}^{1}$ )-methyltransferase of $B$. subtilis, respectively.

\section{Cloning and sequence analysis of the $\sec Y$ gene and other flanking genes.}

The 2.2-kb fragment contained two complete ORFs between two incomplete ORFs (Fig. 1B). The first complete ORF (ORF-Y2, 1,239 bp) encodes a protein (413 amino acids, $45.9 \mathrm{kDa}$ ) that is homologous to the SecY proteins of $B . s u b$ tilis, mycoplasmas, and several other prokaryotes. As with SecA, the OY SecY showed stronger similarities with SecY proteins of gram-positive bacteria, including B. subtilis (34.5\% identity) and Staphylococcus aureus (32.8\% identity), than it did with mollicute mycoplasma (M. genitalium, 29.1\% identity) and gram-negative bacteria (E. coli, $23.7 \%$ identity). The deduced amino acid sequences of ORF-Y2 and SecY proteins of several other prokaryotes were aligned with CLUSTAL W. Two conserved motifs were identified in the deduced amino acid sequence of ORF-Y2 (TLFxLGIXPYIxASIVVQFL and WFxDxINxxGIGNGxSI-LI) (data not shown). These two characteristic signature sequence motifs (1 and 2) have been reported previously for SecY proteins (Akiyama and Ito 1987; Ito 1990). Motif 1 corresponds to the highly conserved second of ten transmembrane-spanning regions of the SecY protein. Motif 2 spans the C-terminal portion of the fourth transmembrane-spanning region, a short intracellular loop, and the N-terminal portion of the fifth transmembrane-spanning region. A putative ribosome-binding site also was upstream from ORF-Y2. The second complete ORF (ORF-Y3, $651 \mathrm{bp}$ ) encodes a putative protein (217 amino acids) that is homologous to adenylate kinase ( $a d k)$ of B. subtilis and mycoplasmas. Homology searches with the upstream and downstream sequences of ORF-Y2 and ORF-Y3 revealed the presence of two incomplete ORFs: ORF-Y1 and
ORF-Y4. ORF-Y1 showed homology with the 50S ribosomal protein L15 gene (rpll5), and ORF-Y4 showed similarity to the methionine aminopeptidase gene (map). These four genes were located on the OY chromosome in the order $5^{\prime}$-rpll5secY-adk-map-3' (Fig. 1B). This arrangement is identical to that in B. subtilis (Kunst et al. 1997) and M. genitalium (Fraser et al. 1995).

\section{Western blot analysis.}

The partial $0.5-\mathrm{kb} \sec A$ gene fragment was expressed in $E$. coli, and the purified protein was used to immunize a New Zealand rabbit. The rabbit antiserum reacted specifically to the overexpressed SecA protein that was used as the antigen (data not shown). To confirm expression of the $\sec A$ gene in the phytoplasma, a crude protein extract was prepared from the phytoplasma-enriched fraction of OY-infected garland chrysanthemum (OY extract) and from uninfected healthy control plants (healthy extract). The two protein fractions were electrophoresed in a sodium dodecyl sulfate (SDS)polyacrylamide gel followed by Western blot analysis. A distinct protein band (approximately $96 \mathrm{kDa}$ ) was detected in the OY extract (Fig. 3, lane D) but not in the healthy extract (Fig. 3 , lane $\mathrm{H}$ ). In the OY extract, several minor bands of smaller size also were observed (Fig. 3, lane D), which may be degraded products of an intact SecA protein. The results indicate that the antiserum reacted specifically with the OY-SecA protein and that SecA was expressed in the OY phytoplasma.

\section{Immunohistochemical analysis.}

To localize the SecA protein in OY, immunohistochemical analysis was performed in OY-infected plant tissues. Sections of OY-infected and healthy plants were incubated with antiSecA immunoglobulin G (IgG) and detected with an enzymelinked detection system. SecA protein was detected specifically in the phloem of an OY-infected plant (Fig. 4A and D) but not in the phloem of a healthy plant (Fig. 4C and E). This distribution of SecA coincides with the phytoplasma reported previously (McCoy 1979). In a cross section, an OY-infected plant showed curved and connected vascular bundles, excessive phloem formation, and necrosis of the abaxial parts of the phloem; thus, the signal of the detected SecA appeared as curved blue bands (Fig. 4A). In a longitudinal section, SecA protein also was observed exclusively in the phloem but not in younger tissues with undifferentiated phloem (Fig. 4D).

\section{DISCUSSION}

This study reports on genes in the phytoplasmal genome encoding the SecA and SecY proteins, which are essential proteins in the Sec protein translocation system. Previous studies have reported on the immunodominant membrane protein genes of aster yellows (Barbara et al. 1998), sweet potato witches' broom (Yu et al. 1998), apple proliferation (Berg et al. 1999), clover phyllody (Davies et al. 1999), and Western X disease phytoplasmas (Blomquist et al. 2001), but $\sec A$ and $\sec Y$ are the first reported genes whose function has been estimated.

The Sec protein translocation system for secreting proteins across the cytoplasmic membrane is best characterized in $E$. coli and is mediated by a complex multistep system comprising at least 11 proteins and one RNA species (Economou 
1999). Among these proteins, SecY, SecE, SecG, and SecA constitute a translocase complex that acts as export machinery at the cytoplasmic membrane. SecA, SecE, and SecY are indispensable for protein translocation and cell viability, whereas SecG is not essential. SecYEG heterotrimers form a membrane-spanning pore, and SecA brings a chaperoneguided secretory protein to the SecYEG pore. SecA uses its ATPase activity to propel protein secretion in a stepwise manner. In M. genitalium and Mycoplasma pneumoniae, however, in which the entire genomes have been sequenced, only the $\sec A$ and $\sec Y$ genes have been recognized to exist as secretory protein genes in databases such as the one located at the Institute for Genomic Research (Fraser et al. 1995), and the $\sec E$ gene has been recognized in the Clusters of Orthologous Groups database. Recently, a global transposon mutagenesis experiment with two mycoplasma genomes indicated that the putative $\sec E$ gene is not essential for cell viability under laboratory growth conditions (Hutchison et al. 1999). Although the components of the Sec system in mycoplasmas were not experimentally analyzed, it was postulated that the mycoplasma secretory system might be functional only with the SecA and SecY proteins. In contrast, nothing is known about the phytoplasma protein secretory system.

The SecA protein was specifically detected in phloem tissues infected with OY phytoplasma with anti-SecA antibody. Although the SecA and SecY proteins play an important role in protein export in bacteria (Ito 1992; Lill et al. 1989), SecY is ubiquitous among living organisms, whereas SecA is not. $\mathrm{SecY}$ homologs have been identified in bacteria as well as in the archaea (Auer et al. 1991) and eukaryotes (Sec61p complex of the endoplasmic reticulum). In contrast, SecA is unique to bacteria and organelles (Pohlschröder et al. 1997) and the sequence homology between OY SecA and putative
SecA from some chloroplasts is remarkably low (data not shown). This explains why the SecA antibody reacted specifically with phytoplasma but not with any host cytoplasmic organelles or matrices in our immunohistochemical analysis.

Antibodies raised against several phytoplasmas were produced previously, including aster yellows (Barbara et al. 1998; Errampalli and Fletcher 1993; Jiang et al. 1988; Lin and Chen 1985), Western X disease (Blomquist et al. 2001), clover phyllody (Davies et al. 1999), apple proliferation (Berg et al. 1999), sweet potato witches' broom (Shen and Lin 1993; Shen and Lin 1994; Yu et al. 1998), grapevine flavescence dorée (Lherminier et al. 1994; Seddas 1993), stolbur (Fos et al. 1992), faba bean phyllody (Saeed et al. 1992), rice yellow dwarf (Chang et al. 1995; Onuki et al. 1992), China tree (Melia azedarach L.) decline (Gomez et al. 1996), and primula yellows (Clark et al. 1989; Milne et al. 1995). These antibodies have provided important tools for the analysis of phytoplasmas such as detection, localization, and purification of the phytoplasma or the target antigens. The anti-SecA antibody and alkaline phosphatase-mediated detection system used here show high sensitivity, fine resolution, and easy handling as a result of low background and signal stability. As Berg et al. (1999) discussed, these advantages probably come from the fact that the anti-SecA antibody was raised against a bacterially expressed protein.

Phylogenetic analysis of the phytoplasmal $16 \mathrm{~S}$ ribosomal DNA sequence determined that phytoplasmas are most closely related to the genus Acholeplasma among mollicutes bacteria (Gundersen et al. 1994; Seemüller et al. 1994). In mycoplasma genomic DNA, the codon UGA encodes tryptophan and not a translation stop. In Acholeplasma laidlawii, however, UGA encodes an "opal" stop codon. In the phytoplasmal genes sequenced in this study, all tryptophan residues were encoded by

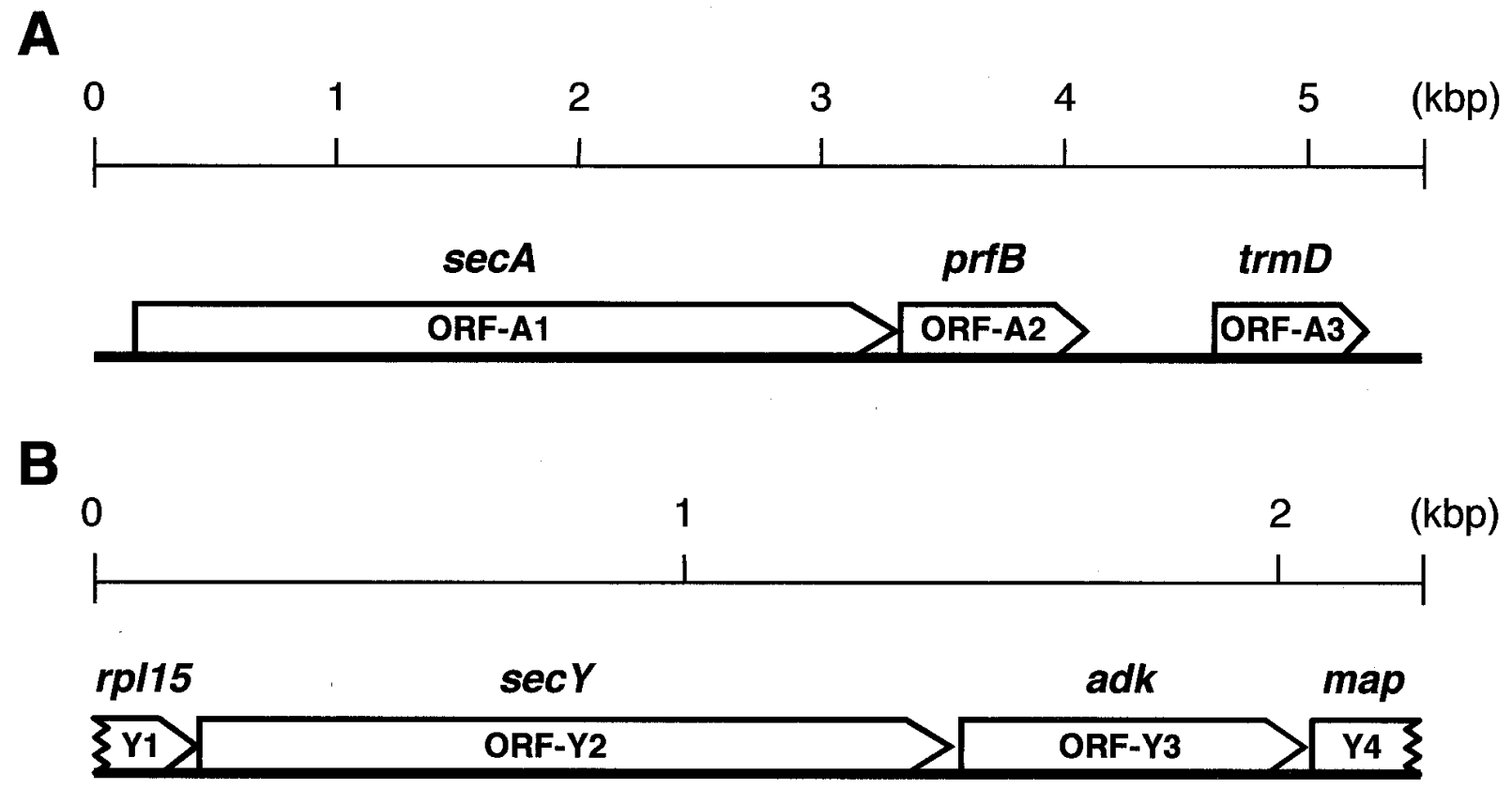

Fig. 1. A, Physical map of the 5.5-kb chromosomal segment, which contains the complete genes encoding SecA ( $\sec A$ ), the protein chain release factor B (prfB), and tRNA-(guanine- $\left.\mathrm{N}^{1}\right)$-methyltransferase $(\operatorname{trmD})$. B, Physical map of the 2.2-kb chromosomal segment, which contains the complete genes encoding $\operatorname{SecY}(\mathrm{sec} Y)$ and adenylate kinase $(a d k)$ and the incomplete genes encoding ribosomal protein L15 (rpll5) and methionine aminopeptidase (map). 
UGG and all stop codons were encoded by UAA, except for the $a d k$ gene, which has a UGA codon at the end of its sequence. If this UGA was translated into a tryptophan residue such as occurs in mycoplasmas the adenylate kinase protein would be $5 \mathrm{kDa}$ larger than in the case of a stop codon. Additional genomic sequence data is needed to clarify this aspect of codon usage in the phytoplasma genome.

It is known that the toxic protein colicin $E_{1}$ and a number of hydrolytic enzymes are exported through the Sec pathway in E. coli. It is thought that the membrane proteins of cell wallless phytoplasmas function directly in the cytoplasm of the host plant and insect cells. The results of this study suggest that the Sec system exists in phytoplasma. In B. subtilis, approximately 300 proteins are thought to be exported from the cytoplasm, and the majority of them, so far, are predicted to follow the Sec pathway. This system is considered to be the most important transport system among the four distinct transport pathways, which also are in B. subtilis (Tjalsma et al. 2000). Moreover, it was predicted that arabinase ( $a b n A$ gene product), which is related to the degradation of plant cell wall polysaccharides, glucanase ( $b g l S$ and $b g l C$ gene products), which is related to cellulose degradation, certain extracellular proteases (aprE, epr, mpr, nprB, nprE, and $v p r$ gene products), and an extracellular xylanase (xynA gene

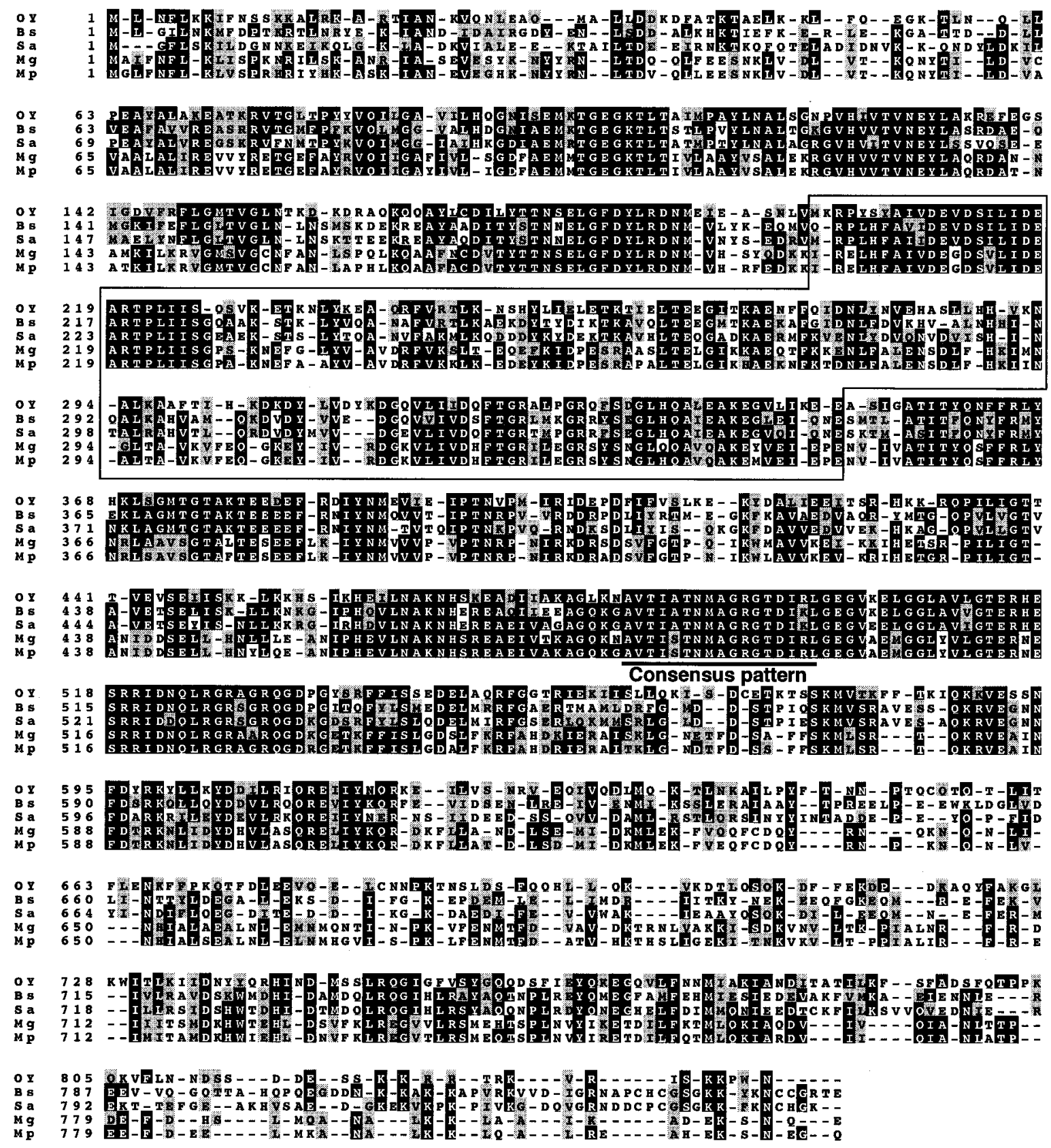

Fig. 2. Protein sequence alignment of SecA. OY, onion yellows phytoplasma; Sa, Staphylococcus aureus; Bs, Bacillus subtilis; Mg, Mycoplasma genitalium; Mp, Mycoplasma pneumoniae. Dark boxes indicate identical residues; shaded boxes indicate similar residues. Region used as the antigen is boxed; consensus pattern of SecA is underlined. 
product) are exported through the Sec pathway in B. subtilis (Tjalsma et al. 2000). Therefore, it is speculated that proteins such as adhesin, proteases, and hydrolytic enzymes could be transported from the phytoplasma cytoplasm to the phytoplasma cell surface or host cytoplasm via the Sec pathway, and these transported proteins may influence pathogenicity.

\section{MATERIALS AND METHODS}

\section{Phytoplasma and phytoplasma-infected plants.}

We used an OY phytoplasma that was isolated in Saga Prefecture, Japan (Shiomi et al. 1996). Healthy garland chrysanthemum (Chrysanthemum coronarium) plants were caged for 5 to 7 days with leafhopper vectors (Macrosteles striifrons) carrying OY. The plants were then sprayed to kill the insects and transferred to a greenhouse $\left(20\right.$ to $\left.30^{\circ} \mathrm{C}\right)$. Approximately 2 months later, DNA was extracted from plants that showed typical symptoms of phytoplasma infection.

\section{DNA extraction from phytoplasma-infected plants.}

Previously described methods with some modifications (Lee et al. 1988; Nishigawa et al. 2001) were used to construct a genomic DNA library with DNA extracted from phytoplasma-enriched fractions prepared from OY-infected or healthy garland chrysanthemum plants.

\section{Cloning phytoplasma DNA.}

The genomic DNA of OY was digested completely with restriction endonucleases HincII, HindIII, and XbaI and ligated into pUC18. The ligated genomic DNA was transformed into E. coli strain JM109. The cloned DNA fragments were then excised from pUC18 and prepared as probes for dot blot hybridization to DNA samples extracted from OY-infected and healthy plants. DNA probes were labeled with alkaline phosphatase, and the hybridization products were detected with the ECF Chemifluorescent Detection System (Amersham Pharmacia Biotech, Tokyo, Japan), according to the manufacturer's protocols.

\section{DNA sequencing and homology analysis.}

The DNA inserts were sequenced with Taq FS DNA polymerase and fluorescent-dideoxy terminators. The resultant DNA fragments were separated by electrophoresis and analyzed with an automated DNA sequencer (Model 377, Applied Biosystems, Tokyo, Japan). The similarity of all five ORFs to known genes was analyzed with sequence interpretation tools (Institute of Medical Science, University of Tokyo, Tokyo, Japan) and the BLAST algorithm (Altschul et al. 1990). CLUSTAL W, version 1.7 (Thompson et al. 1994), was used to align amino acid sequences of proteins that showed similarity with each ORF. Sequences used for comparison were SecA of S. aureus, O06446; SecA of B. subtilis, P28366; SecA of M. genitalium, P47318; SecA of M. pneumoniae, P75559; SecA of E. coli, P10408; SecY of S. aureus, O08387; SecY of B. subtilis, P16336; SecY of M. genitalium, P47416; SecY of M. pneumoniae, Q59548; SecY of E. coli, P03844.

\section{Preparation of antiserum against the SecA protein.}

The pET system (Novagen, Madison, WI, U.S.A.) was used to generate a histidine-tagged $\mathrm{Sec} A$ fusion protein for expres- sion in E. coli. A $0.5-\mathrm{kb} \sec A$ gene fragment was amplified by polymerase chain reaction with primers SecA-N (5'-TTG AAT TCC ATA TGA AAC GCC CTT ACA GTT ATG C-3') and SecA-C (5'-TGA GCT CGA GAG CTT CTT CTT TAA TTA ATA CTC CTT-3'). The amplicon was then digested with NdeI and XhoI and inserted into pET30a. The histidinetagged SecA construct was expressed in E. coli BL21(DE3) cells. Cell extracts were applied to a nickel NTA column (Novagen), washed with TBS buffer ( $20 \mathrm{mM}$ Tris-HCl, $\mathrm{pH} 7.9$, and $500 \mathrm{mM} \mathrm{NaCl}$ ), and the fusion protein was eluted with TBS buffer containing $1 \mathrm{M}$ imidazole. The purity of the protein was checked by SDS-polyacrylamide gel electrophoresis (PAGE) (data not shown). Antibodies against the SecA protein were generated in a white New Zealand rabbit by injecting homogeneous protein in water emulsified with 1:1 volume of Freund's complete adjuvant (Difco, Detroit, MI, U.S.A.). The rabbit was boosted with a second injection after 2 weeks, and serum was obtained after an additional 2 weeks. The IgG fractions were purified from the crude serum with a Protein-A column (Bio-Rad, Kanagawa, Japan).

\section{PAGE and Western blotting.}

Crude protein extracts were prepared from healthy and OYinfected plants by the method used to obtain the phytoplasmaenriched fraction for DNA isolation. The protein fractions were separated on $8 \%$ (vol/vol) SDS-polyacrylamide gels with Laemmli buffer. Gels were electroblotted (Bio-Rad) onto polyvinylidene difluoride membranes (Millipore, Tokyo, Ja-

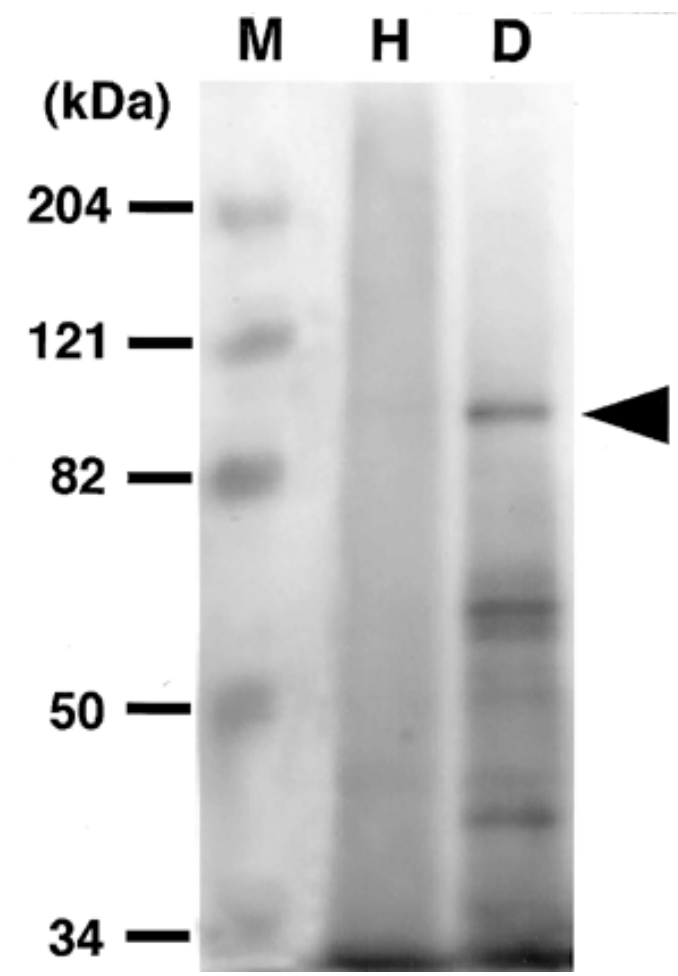

Fig. 3. Immunoblot analysis with anti-SecA immunoglobulin $\mathrm{G}$ (IgG). Extracts from the healthy $(\mathrm{H})$ and onion yellows plytoplasma-infected (D) plants were separated by $8 \%$ sodium dodecyl sulfate-polyacrylamide gel electrophoresis. Gels were blotted onto polyvinylidene difluoride membranes and reacted with anti-SecA IgG. Arrowhead indicates the phytoplasma-specific band with a molecular mass of approximately $96 \mathrm{kDa}$. M, molecular weight marker (Bio-Rad, Kanagawa, Japan). 
pan). Membrane blots were processed for immunological analysis, as described by Sambrook et al. (1989). Membranes were incubated in blocking reagent (TBS buffer containing $0.05 \%$ [vol/vol] Tween 20 [TBST] and 4\% nonfat dry milk), followed by incubation with an antibody against SecA protein diluted to $3 \mu \mathrm{g}$ per $\mathrm{ml}$. After incubation with the first antibody, the membranes were washed with TBST and hybridized with alkaline phosphatase-tagged secondary antibodies (Amersham Pharmacia Biotech) that were diluted 1:5,000 in TBST. The blots were developed with AlkPhos detection reagent (Amersham Pharmacia Biotech), according to the manufacturer's protocols, and visualized with the FluorImager595 (Molecular Dynamics, Tokyo, Japan).

\section{Immunohistochemical analysis.}

Tissues were fixed overnight, at $4{ }^{\circ} \mathrm{C}$, in $4 \%$ (wt/vol) paraformaldehyde in $0.1 \mathrm{M}$ sodium phosphate buffer ( $\mathrm{pH} 7.4$ ), dehydrated through a graded ethanol series and a $t$-butanol

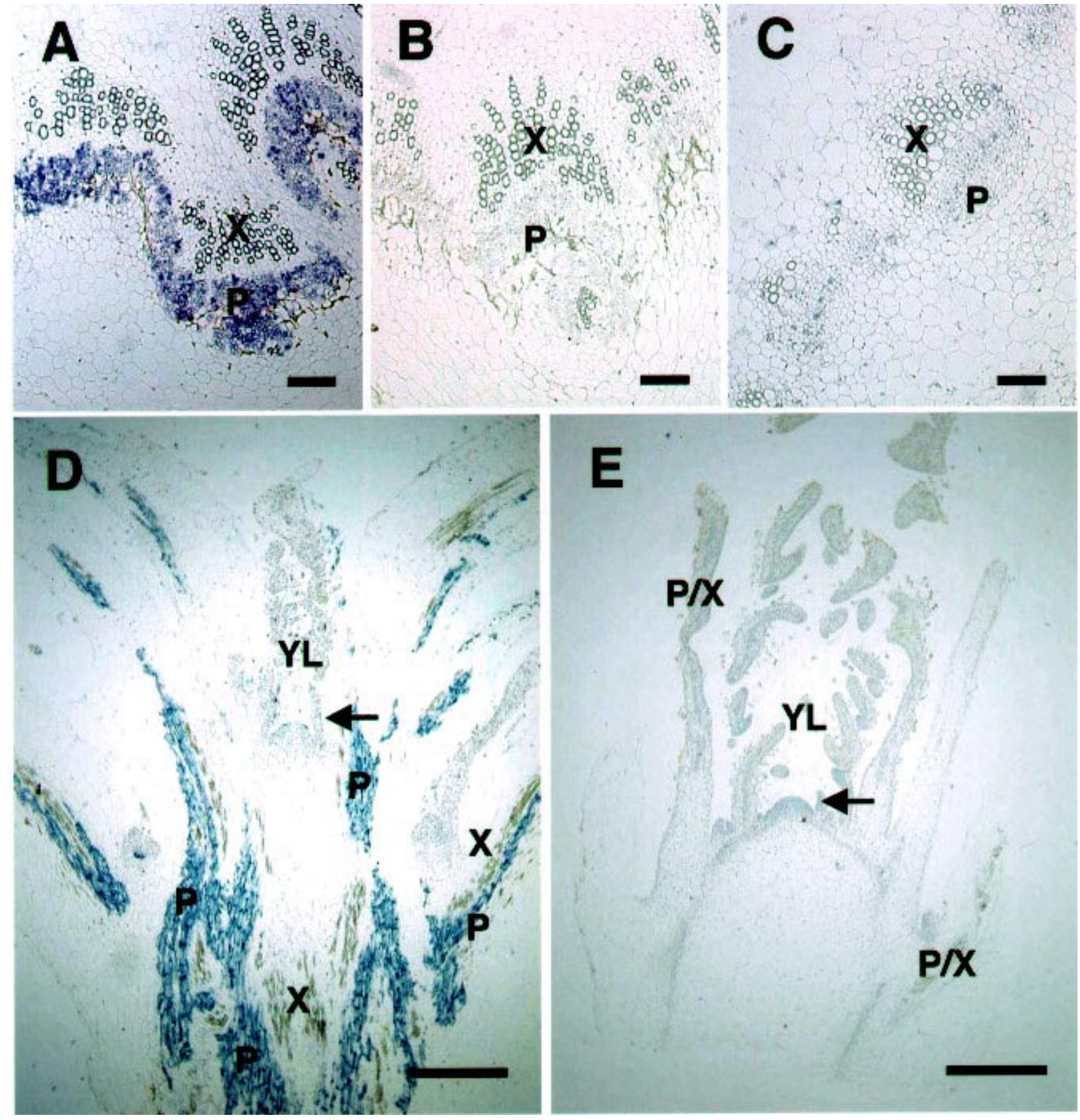

Fig. 4. Immunohistochemical detection of SecA protein in a vascular bundle of the stem of garland chrysanthemum plant. Stem cross sections from A, onion yellows phytoplasma (OY)-infected or $\mathbf{C}$, healthy plants were reacted with antibodies raised against the SecA protein. Cross section from an OY-infected plant was reacted with B, preimmune immunoglobulin G (IgG.). Stem longitudinal sections of D, OY-infected or $\mathbf{E}$, healthy plants were reacted with anti-SecA IgG. Localization of the SecA protein is visualized with blue pigmentation. P, phloem; X, xylem; YL, younger leaf. E, Corresponding phloem and xylem were not distinguishable and are labeled as P/X. Arrows indicate the apical meristem. Scale bars = A-C, $0.1 \mathrm{~mm} ; \mathbf{D}-\mathbf{E}, 0.5 \mathrm{~mm}$. 
series (Sass 1958), and embedded in Paraplast Plus (Sherwood Medical, St. Louis, MO, U.S.A.). Microtome sections (10 $\mu \mathrm{m}$ thick) were applied to charged glass slides (Fisher Scientific, Pittsburgh, PA, U.S.A.). The sections were deparaffinized in xylene, rehydrated through a graded ethanol series, and washed twice in distilled water for $10 \mathrm{~s}$ each and three times in PBS buffer $\left(120 \mathrm{mM} \mathrm{NaCl}, 7 \mathrm{mM} \mathrm{Na} \mathrm{HPO}_{4}, 3 \mathrm{mM}\right.$ $\mathrm{NaH}_{2} \mathrm{PO}_{4}$, and $2.7 \mathrm{mM} \mathrm{KCl}$ ) for $5 \mathrm{~min}$ each. They were then incubated in blocking buffer $(10 \%$ fetal calf serum and $0.02 \%$ $\mathrm{NaN}_{3}$ in PBS buffer) for $30 \mathrm{~min}$ at room temperature and incubated with $3 \mu \mathrm{g}$ per $\mathrm{ml}$ of dilution of the anti-SecA IgG in blocking buffer at $4{ }^{\circ} \mathrm{C}$ overnight. The tissue sections were washed four times for $10 \mathrm{~min}$ in PBS buffer with $1.05 \%$ Tween 20 and incubated in a 1:1,000 dilution of alkaline phosphatase-coupled goat anti-rabbit IgG secondary antibody (Vector Laboratories, Burlingame, CA, U.S.A.) in blocking buffer. After a 1-h incubation, sections were washed four times for $10 \mathrm{~min}$ in PBS buffer with $1.05 \%$ Tween 20, then washed twice with alkaline phosphatase (AP) buffer $(100 \mathrm{mM}$ $\mathrm{NaCl}, 50 \mathrm{mM} \mathrm{MgCl}$, and $100 \mathrm{mM}$ Tris-HCl, $\mathrm{pH}$ 9.5). For color development, sections were incubated with $0.34 \mathrm{mg}$ of nitroblue tetrazolium salt per $\mathrm{ml}$ and $0.175 \mathrm{mg}$ of 5-bromo-4chloro-3-indolyl phosphate toluidinium salt per $\mathrm{ml}$ in AP buffer at room temperature in the dark. The reaction was stopped by immersing the slides in Tris-EDTA buffer, $\mathrm{pH}$ 7.5. The sections were dehydrated through a graded ethanol series and then mounted in Eukitt (O. Kindler, Freiburg, Germany).

\section{ACKNOWLEDGMENTS}

We thank S. Hatano for his excellent technical assistance. This work was supported by the Promotion of Basic Research Activities for Innovative Biosciences (PROBRAIN) program of Japan and by grants-in-aid from the Ministry of Education, Science and Culture of Japan (09460155).

\section{LITERATURE CITED}

Akiyama, Y., and Ito, K. 1987. Topology analysis of the SecY protein, an integral membrane protein involved in protein export in Escherichia coli. EMBO J. 6:3465-3470.

Altschul, S. F., Gish, W., Miller, W., Myers, E. W., and Lipman, D. J. 1990. Basic local alignment search tool. J. Mol. Biol. 215:403-410.

Auer, J., Spicker, G., and Bock, A. 1991. Presence of a gene in the archaebacterium Methanococcus vannielii homologous to $\sec Y$ of eubacteria. Biochimie 73:683-688.

Barbara, D. J., Davies, D. L., and Clark, M. F. 1998. Cloning and sequencing of a major membrane protein from chlorante (aster yellows) phytoplasma. (Abstr.) Page 183 in: Proc. Int. Meet. Int. Organ. Mycoplasmol. Australian Society of Microbiology, Sydney.

Berg, M., Davies, D. L., Clark, M. F., Vetten, H. J., Maier, G., Marcone, C., and Seemüller, E. 1999. Isolation of the gene encoding an immunodominant membrane protein of the apple proliferation phytoplasma, and expression and characterization of the gene product. Microbiology 145:1937-1943.

Blomquist, C. L., Barbara, D. J., Davies, D. L., Clark, M. F., and Kirkpatrick, B. C. 2001. An immunodominant membrane protein gene from the Western X-disease phytoplasma is distinct from those of other phytoplasmas. Microbiology 147: 571-580.

Chang, F. L., Chen, C. C., and Lin, C. P. 1995. Monoclonal antibody for the detection and identification of a phytoplasma associated with rice yellow dwarf. Eur. J. Plant. Pathol. 101:511-518.

Clark, M. F., Morton, A., and Buss, S. L. 1989. Preparation of mycoplasma immunogens from plants and a comparison of polyclonal and monoclonal antibodies made against primula yellows MLOassociated antigens. Ann. Appl. Biol. 114:111-124.

Davies, D. L., Clark, M. F., and Barbara, D. J. 1999. Cloning and se- quencing of the genes determining a major membrane protein associated with the chlorante isolate of aster yellows and clover phyllody. Internet Conf. Phytopathogenic Mollicutes www.uniud.it/ phytoplasma/pap/davi7140.html.

Economou, A. 1999. Following the leader: Bacterial protein export through the Sec pathway. Trends Microbiol. 7:315-320.

Errampalli, D., and Fletcher, J. 1993. Production of monospecific polyclonal antibodies against aster yellows mycoplasmalike organismassociated antigen. Phytopathology 83:1279-1282.

Fos, A., Danet, J. L., Zreik, L., Garnier, M., and Bove, J. M. 1992. Use of a monoclonal antibody to detect the stolbur mycoplasmalike organism in plants and insects and to identity a vector in France. Plant Dis. 76:1092-1096.

Fraser, C. M., Gocayne, J. D., White, O., Adams, M. D., Clayton, R. A., Fleischmann, R. D., Bult, C. J., Kerlavage, A. R., Sutton, G., Kelley, J. M., Fritchman, J. L., Weidman, J. F., Small, K. V., Sandusky, M., Fuhrmann, J., Nguyen, D., Utterback, T. R., Saudek, D. M., Phillips, C. A., Merrick, J. M., Tomb, J.-F., Dougherty, B. A., Bott, K. F., Hu, P.-C., and Lucier, T. S. 1995. The minimal gene complement of $M y$ coplasma genitalium. Science 270:397-403

Gomez, G. G., Conci, L. R., Ducasse, D. A., and Nome, S. F. 1996. Purification of the phytoplasma associated with china-tree (Melia azedarach L.) decline and the production of a polyclonal antiserum for its detection. J. Phytopathol. 144:437-477.

Gundersen, D. E., Lee, I. M., Rehner, S. A., Davis, R. E., and Kingsbury, D. T. 1994. Phylogeny of mycoplasmalike organisms (phytoplasmas): A basis for their classification. J. Bacteriol. 176:5244-5254.

Hutchison, C. A., III, Peterson, S. N., Gill, S. R., Cline, R. T., White, O., Fraster, C. M., Smith, H. O., and Venter, J. C. 1999. Global transposon mutagenesis and a minimal mycoplasma genome. Science 286:21652169.

Ito, K. 1990. Structure, function, and biogenesis of SecY, an integral membrane protein involved in protein export. J. Bioenerg. Biomembr. 22:353-367.

Ito, K. 1992. SecY and integral membrane components of the Escherichia coli protein translocation system. Mol. Microbiol. 6:24232428.

Jiang, Y. P., Lei, J. D., and Chen, T. A. 1988. Purification of aster yellows agent from diseased lettuce using affinity chromatography. Phytopathology 78:828-831.

Kirkpatrick, B. C. 1992. Mycoplasma-like organisms: Plant and invertebrate pathogens. Pages 4050-4067 in: The Prokaryotes. A. Balows, H. G. Truper, M. Dworkin, W. Harder, and K. H. Schleifer, eds. Springer-Verlag, New York.

Kuboyama, T., Huang, C.-C., Lu, X., Sawayanagi, T., Kanazawa, T., Kagami, T., Matsuda, I., Tsuchizaki, T., and Namba, S. 1998. A plasmid isolated from phytopathogenic onion yellows phytoplasma and its heterogeneity in the pathogenic phytoplasma mutant. Mol. Plant Microbe Interact. 11:1031-1037.

Kunst, F., Ogasawara, N., Moszer, I., Albertini, A. M., Alloni, G., Azevedo, V., Bertero, M. G., Bessieres, P., Bolotin, A., Borchert, S., Borriss, R., Boursier, L., Brans, A., Braun, M., Brignell, S. C., Bron, S., Brouillet, S., Bruschi, C. V., Caldwell, B., Capuano, V., Carter, N. M., Choi, S. K., Codani, J. J., Connerton, I. F., Danchin, A., et al. 1997. The complete genome sequence of the Gram-positive bacterium Bacillus subtilis. Nature 390:249-256.

Lee, I. M., and Davis, R. E. 1992. Mycoplasmas which infect plant andinsects. Pages 379-390 in: Mycoplasmas: Molecular Biology and Pathogenesis. R. N. McElhaney, L. R. Finch, J. B. Baseman, and J. Maniloff, eds. American Society for Microbiology, Washington, D. C.

Lee, I. M., Davis, R. E., Hammond, R., and Kirkpatrick, B. C. 1988. Cloned riboprobe for detection of a mycoplasmalike organism. Biochem. Biophys. Res. Commun. 155:443-448.

Lherminier, J., Courtois, M., and Caudwell, A. 1994. Detection of the distribution and multiplication sites of flavescence dorée mycoplasma-like organism in the host plant Vicia faba by ELISA and immunocytochemistry. Phys. Mol. Plant Pathol. 45:125-138.

Lill, R., Cunningham, K., Brundage, L. A., Ito, K., Oliver, D., and Wickner, W. 1989. SecA protein hydrolyzes ATP and is an essential component of the protein translocation ATPase of Escherichia coli. EMBO J. 8:961-966.

Lin, C.-P., and Chen, T. A. 1985. Monoclonal antibodies against the aster yellows agent. Science 227:1233-1235.

McCoy, R. E. 1979. Plant and insect mycoplasma. Pages 229-264 in: 
Mycoplasmas, Vol. 3: Mycoplasmas and Yellows Diseases. R. E. Whitcomb and J. G. Tully, eds. Academic Press, New York.

McCoy, R. E., Caudwell, A., Chang, C. J., Chen, T. A., Chiykowski, L. N., Cousin, M. T., Dale De Leeuw, G. T. N., Golino, D. A., Hackett, K. J., Kirkpatrick, B. C., Marwitz, R., Petzold, H., Sinha, R. H., Sugiura, M., Whitcomb, R. F., Yang, I. L., Zhu, B. M., and Seemüller E. 1989. Plant disease associated with mycoplasma-like organisms. Pages 546-640 in: The Mycoplasmas, Vol. 5: Plant Diseases Associated With Mycoplasma-Like Organisms. R. F. Whitcomb and J. G. Tully, eds. Academic Press, New York.

Milne, R. G., Ramasso, E., Lenzi, R., Masenga, V., Sarindu, S., and Clark, M. F. 1995. Pre- and post-embedding immunogold labeling and electron microscopy in plant host tissue of three antigenically unrelated MLOs: Primula yellows, tomato big bud and Bermuda grass white leaf. Eur. J. Plant Pathol. 101:57-67.

Murphy, J. R., Pappenheimer, A. M., Jr., and De Borms, S. T. 1974. Synthesis of diphtheria tox-gene products in Escherichia coli extracts. Proc. Natl. Acad. Sci. USA 71:11-15.

Namba, S., Oyaizu, H., Kato, S., Iwanami, S., and Tsuchizaki, T. 1993. Phylogenetic diversity of phytopathogenic mycoplasma-like organisms. Int. J. Syst. Bacteriol. 43:461-467.

Nishigawa, H., Miyata, S., Oshima, K., Sawayanagi, T., Komoto, A., Kuboyama, T., Matsuda, I., Tsuchizaki, T., and Namba, S. 2001. In planta expression of a protein encoded by the extrachromosomal DNA of phytoplasma and related to geminivirus replication proteins. Microbiology 147:507-513.

Onuki, M., Hayashi, T., and Sakai, J. 1992. Detection of antigenic proteins of mycoplasmalike organism (MLO) associated with rice yellow dwarf from infected rice plants. Ann. Phytopathol. Soc. Jpn. 58:613.

Pappenheimer, A. M., Jr. 1977. Diphtheria toxin. Annu. Rev. Biochem. 46:69-94.

Pohlschröder, M., Prinz, W. A., Hartmann, E., and Beckwith, J. 1997. Protein translocation in the three domains of life: Variations on a theme. Cell 91:563-566.

Saeed, E., Rage, P., and Cousin, M. T. 1992. Detection of the antigenic protein size associated with faba bean phyllody MLO by using (SDSPAGE) electrophoresis and immunotransfer. J. Phytopathol. 136:1-8.

Sambrook, J., Fritsch, E. F., and Maniatis, T. 1989. Molecular Cloning: A Laboratory Manual. Cold Spring Harbor Laboratory, Cold Spring Harbor, NY, U.S.A.

Sass, A. E. 1958. Botanical Microtechnique, 3rd ed. Iowa State University Press, Ames, U.S.A.

Seddas, A., Meignoz, R., Daire, X., Boudon-Padieu, E., and Caudwell, A. 1993. Purification of grapevine flavescence dorée MLO (mycoplasma-like organism) using immunoaffinity. Curr. Microbiol. 27:229-236.
Seemüller, E., Schneider, B., Maurer, R., Ahrens, U., Daire, X., Kison, H., Lorenz, K. H., Firrao, G., Avinent, L., and Sears, B. B. 1994. Phylogenetic classification of phytopathogenic mollicutes by sequence analysis of 16S ribosomal DNA. Int. J. Syst. Bacteriol. 44:440-446.

Shen, W. C., and Lin, C. P. 1993. Production of monoclonal antibodies against a mycoplasmalike organism associated with sweetpotato witches' broom. Phytopathology 83:671-675.

Shen, W. C., and Lin, C. P. 1994. Application of immunofluorescent staining and tissue-blotting techniques for the detection of a mycoplasmalike organism associated with sweetpotato witches' broom. Plant Pathol. Bull. 3:79-83.

Shiomi, T., Tanaka, M., Wakiya, H., and Zenbayashi, R. 1996. Occurrence of Welsh onion yellows. Ann. Phytopathol. Soc. Jpn. 62:258-260.

Simpson, A. J., Silvestri, M. L., Siqueira, W. J., De Souza, A. A., De Souza, A. P., Terenzi, M. F., Truffi, D., Tsai, S. M., Tsuhako, M. H., Vallada, H., Van Sluys, M. A., Verjovski-Almeida, S., Vettore, A. L., Zago, M. A., Zatz, M., Meidanis, J., Setubai, J. C. et al. 2000. The genome sequence of the plant pathogen Xylella fastidiosa. The Xylella fastidiosa Consortium of the Organization for Nucleotide Sequencing and Analysis, Sao Paulo, Brazil. Nature 406:151-157.

Spangler, B. D. 1992. Structure and function of cholera toxin and the related Escherichia coli heat-labile enterotoxin. Microbiol. Rev. 56:622-647.

Thompson, J. D., Higgins, D. G., and Gibson, T. J. 1994. CLUSTAL W: Improving the sensitivity of progressive multiple sequence alignment through sequence weighting, positions-specific gap penalties and weight matrix choice. Nucleic Acids Res. 22:4673-4680.

Tjalsma, H., Bolhuis, A., Jongbloed, J. D., Bron, S., Van Dijl, J. M. 2000. Signal peptide-dependent protein transport in Bacillus subtilis: A genome-based survey of the secretome. Microbiol. Mol. Biol. Rev. 64:515-547.

Wei, W., Plovanich-Jones, A., Deng, W. L, Jin, Q. L., Collmer, A., Huang, H. C., and He, S. Y. 2000. The gene coding for the Hrp pilus structural protein is required for type III secretion of Hrp and Avr proteins in Pseudomonas syringae pv. tomato. Proc. Natl. Acad. Sci. USA. 97:2247- 2252

Yu, Y.-L., Yeh, K.-W., and Lin, C.-P. 1998. An antigenic protein gene of a phytoplasma associated with sweet potato witches' broom. Microbiol. 144:1257-1262.

\section{AUTHOR-RECOMMENDED INTERNET RESOURCES}

Clusters of Orthologous Groups database: www.ncbi.nlm.nih.gov/COG GenomeNet: www.genome.ad.jp

Institute for Genomic Research: ww.tigr.org/tdb/mdb/mdbcomplete.html 